\title{
Phytochemical and Antibacterial Properties of Calotropis Procera (Ait) R. Br. (Sodom Apple) Fruit and Bark Extracts
}

\author{
M. M. Mainasara ${ }^{1}$, B. L. Aliero ${ }^{1}$, A. A. Aliero ${ }^{1, *}$, S. S. Dahiru ${ }^{2}$ \\ ${ }^{1}$ Department of Biological Sciences, Usmanu Danfodiyo University, Sokoto, Nigeria \\ ${ }^{2}$ Zamfara State College of Art and Science, Zamfara State, Nigeria
}

\begin{abstract}
Phytochemical and antibacterial activities of water, methanol and ethanol extracts obtained from the fruit and bark of Calotropis procera were investigated in an attempt to evaluate its medicinal potentials. The phytochemical screening revealed the presence of alkaloids, flavonoids, tannins, saponins, and cardiac glycosides with a very high content in water extracts. The concentration of the phytochemical constituents were in the order of water $>$ methanol $>$ ethanol. Antibacterial activity was determined against Pseudomonas aeruginosa, Salmonella typhi, Escherichia coli and Streptococcus pyrogenes. Water extracts showed inhibition against the tested organisms at $30 \mathrm{mg} / \mathrm{ml}$. Methanol and ethanol extracts did not show an appreciable activity at 30 and $90 \mathrm{mg} / \mathrm{ml}$ respectively. The result of this study validates the use of water extract of this species in ethnomedicine and could provide a lead in the isolation of antibacterial agents from water extracts of Calotropis procera.
\end{abstract}

Keywords Calotropis Procera, Antibacterial, Phytochemical, Ethno Medicine

\section{Introduction}

Many research efforts have been directed towards the provision of empirical proofs to back up the use of plants species in trade and medicinal practices in recent years $(\mathrm{Ojo}$ et al., 2005). Many researchers have examined the effects of plants used traditionally or by indigenous healers to support treatment of various diseases; scientific validations are being made globally to get evidence for traditionally reputed herbal plants. However, there still exist a large number of plants with tremendous medicinal potentials that have not been investigated.

Calotropis procera belongs to family Asdepiadaceae, used medicinally, to treat boils, infected wounds and other skin problems in people and to treat parasitic skin infestation in animals (Himalaya, 2002). It also yield ash for making gun powder, the latex is processed and use in treating vertigo, baldness, hair fall, tooth aches, intermittent fevers, rheumatoid/joints swellings and paralysis (Vohra, 2004). The whole plant when dried and consumed is a good tonic, antihelmintic and as an expectorant (Agharkar, 1991; Warrier et al., 1996). The roots, besides being endowed with similar qualities serves as an effective laxative. Traditionally, the dried root

* Corresponding author:

aaaliero@yahoo.com (A. A. Aliero)

Published online at http://journal.sapub.org/ijmb

Copyright (C) 2011 Scientific \& Academic Publishing. All Rights Reserved is powdered and effectively used to cure bronchitis, asthma, leprosy, eczema and elephantiasis, hepatic and splenic enlargement (Vohra, 2004). The milky juice is regarded as drastic purgative and caustic flowers were considered to improve digestion, catarrh and increases appetite (Oudhia, 2001). The pungent latex extracted from the leaf and flowers of $C$. procera is processed and used in the commercial preparation of eye tonic (Vohra, 2004). The juice was also found to induce abortion in women and tanners use the milky juice to remove hair from the hides (Singh et al., 1996). Traditionally, the leaves of the plant are warmed and tied around any body organ in pain. It practically useful in backache and joint pains, warm leaves also relieve from stomach ache if tied around. Inhalation of burnt leaf cures headache. The traditional folk healers use the milky latex of C. procera for several ailments. Leaf latex if applied on fresh cut, stops bleeding immediately. Recent investigation has found that the alkaloids calotropin, calotaxein and uskerin are stimulant to heart (Ashwari, 2009). it is also used by traditional medicine practitioner in Gwari communities for the treatment of ring worms (Kuta, 2008). This paper reports on the phytochemical and antibacterial properties of $C$. procera growing in Sudan Savanna region of Nigeria.

\section{Materials and Method}

\subsection{Sample Collection and Preparation}


Fresh leaves, root, bark and fruits of $C$. procera were collected from Tudun Wada ward of Gusau, Zamfara state. The species was identified and authenticated at the Herbarium of the Department of Biological Sciences Usmanu Danfodiyo University, Sokoto, where the voucher specimen was prepared and deposited. The plant parts were sun dried and pulverized into coarse powder using mortar and pestle. The powdered samples were sieved and stored in polythene bags until when required for use, in accordance with method of Onomire and Olorunfemi (1998).

\subsection{Extraction and Preparation of Material for Phyto- chemical Screening}

The powdered plant parts were separately extracted with $95 \%$ ethanol, methanol and water. The extracts were filtered using Whitman No. 1 filter paper and the solutions were concentrated using water bath. The extracts were stored in different containers apparently labelled and kept in polythene bags before analysis.

\subsection{Antibacterial Screening}

\section{Test organisms}

The microorganisms used for antibacterial activity, were Staphylococcus aureus, Pseudomonas aeruginosa, Salmonella typhi, Escherichia coli and Streptococcus pyrogenes, obtained from Microbiology Department, Usmanu Danfodiyo University Teaching Hospital, Sokoto.

\section{Antibacterial activity}

The well plate (Ditch) diffusion method and Disk Diffusion assay were used to determine the growth inhibition of bacteria by plant extracts as described by Mohammad and Dabai (2008), the nutrient agar (Muller Hinton) plates were prepared and seeded with the test organisms. Four holes of $6.0 \mathrm{~mm}$ diameter each were made in the plates with a sterile cork borer and filled with 30,60, 90 and $120 \mathrm{mg} / \mathrm{ml}$ extracts respectively. The inoculated plates were allowed to congeal for $30 \mathrm{~min}$ to allow pre diffusion time and then incubated at $370 \mathrm{C}$ for $24 \mathrm{hrs}$. The plates were examined for evidence of zones of inhibition which appear as a clear area around the holes (Cheesbrough, 2001). The diameter of such zone of inhibition was measured using a transparent meter ruler and the value was recorded and expressed to the nearest millimeter.

\section{Phytochemical screening}

Adopting the methods of Sofowora (1982), the water, methanol and ethanol extracts of $C$. procera fruit and bark were tested for the presence of alkaloids, flavonoids, tannins, saponins and glycosides.

\section{Results and Discussion}

The result of phytochemical screening of water, methanol and ethanol extracts of $C$. procera root and leaves revealed the presence of alkaloids, flavonoids, saponins, tannin and glycosides (Table 1). The concentration of the various classes of secondary metabolite varies amongst the extracts evaluated. In all the extracts evaluated, the concentration of the constituents are in order of water $>$ methanol $>$ ethanol. The presence of these components in this species is an indication that it may perhaps have some medicinal potential. This is probably due to the fact that each of the components identified has one therapeutic usage or another. For instance, plants rich in saponins have immune boosting and anti inflammatory properties (Kenner and Requena, 1996). Similarly tannins have been reported to have antibacterial potential due to their basic character that allows them to react with proteins to form stable water soluble compounds thereby killing the Bacteria by directly damaging its cell membrane (Elmarie and Johan, 2001). The antibacterial activities of alkaloids and flavonoids have been reported by a number of authors (Aliero et al., 2008; Yasmin et al., 2008).

Table 1. Phytochemical constituents of $C$. procera

\begin{tabular}{|c|c|c|c|c|c|c|}
\hline \multicolumn{7}{|c|}{ Extracts } \\
\hline \multicolumn{7}{|c|}{ Water Methanol Ethanol } \\
\hline Constituents & \multicolumn{2}{|c|}{ Fruit Bark } & \multicolumn{2}{|c|}{ Fruit Bark } & \multicolumn{2}{c|}{ Fruit Bark } \\
\hline Tannins & + & + & + & + & - & - \\
\hline Flavonoids & ++ & ++ & + & - & ++ & - \\
\hline Saponins & & & & & & \\
\hline Emulsification & ++ & ++ & - & - & - & - \\
\hline Frothing & ++ & - & & & & \\
\hline Alkaloids & & & & & & \\
\hline Mayer`s reagent & +++ & ++ & & & & \\
\hline Wagner`s reagent & + & ++ & - & - & + & ++ \\
\hline Saponins Glycosides & + & - & + & + & - & - \\
\hline Cardiac Glycosides & ++ & + & & & + & + \\
\hline Steroids & ++ & + & + & - & + & - \\
\hline Balsams & - & - & & & - & - \\
\hline Volatile Oil & ++ & + & + & + & + & - \\
\hline Glycosides & + & + & - & - & - & - \\
\hline
\end{tabular}

Key: $+++=$ present in high concentration, $++=$ moderately present, $+=$ Trace, $-=$ Absent

The result of the antibacterial activity measured in term of diameter of zone of inhibition, the antibacterial activity of $\mathrm{C}$. procera on the test organisms using water, methanol and ethanol extracts of fruit and bark exhibited antibacterial activity against both the Gram positive and Gram negative bacteria. Generally, Salmonella typhi and Pseudomonas aeruginosa was observed to be the most susceptible organisms, this result is similar to that of Yesmin et al. (2008). Staphylococcus aureus is least susceptible, also reported in Aliero et al. (2008). In the methanol extracts of root $S$. pyrogenes and $S$. aureus showed no appreciable activity and also in ethanol extracts of root $S$. aureus, Salmonella typhi and $E$. coli showed no activity, this was also reported by Yesmin et al. (2008). Likewise in water extracts of root, all the test organisms showed no activity except against Pseudomonas aeruginosa, similar observation was also done by Usman et al. (2005). Methanol, ethanol and water extracts of C. procera showed significant antibacterial activity against both the Gram positive and Gram negative bacterial strain (Yesmin et al., 2008). The result of this study justifies the use of water extracts of $C$. procera in ethnomedicine for the treatment of infectious diseases caused by bacteria. 


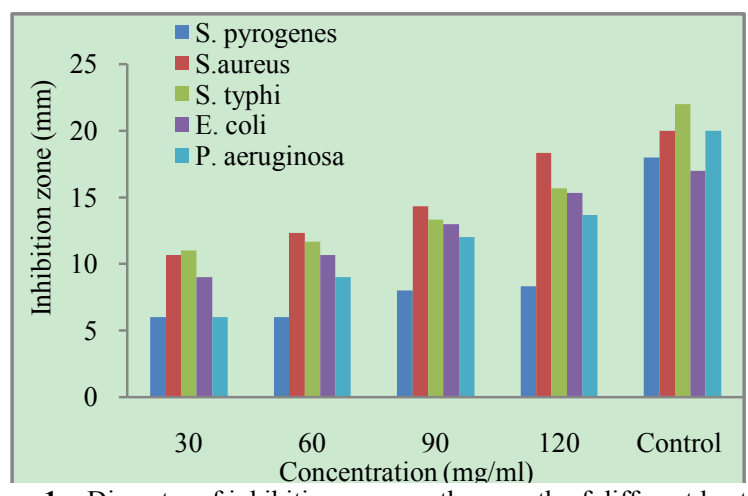

Figure 1. Diameter of inhibition zone on the growth of different bacterial species due to application of different concentration of water extract of $C$. procera bark

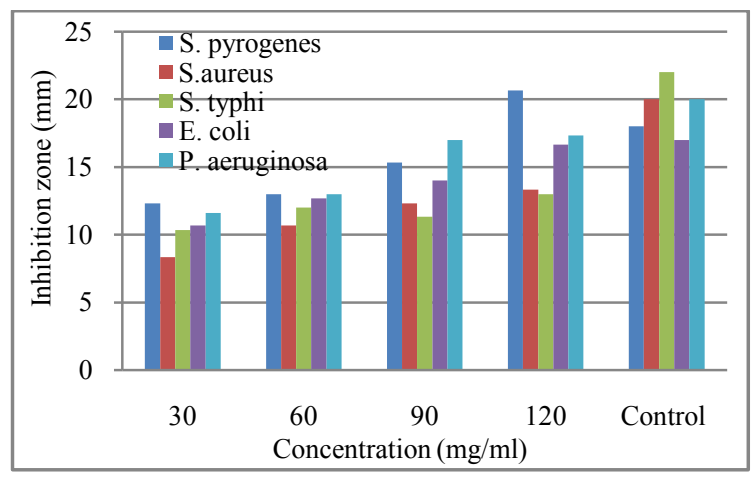

Figure 2. Diameter of inhibition zone on the growth of different bacterial species due to application of different concentration of water extract of $C$. procera fruit

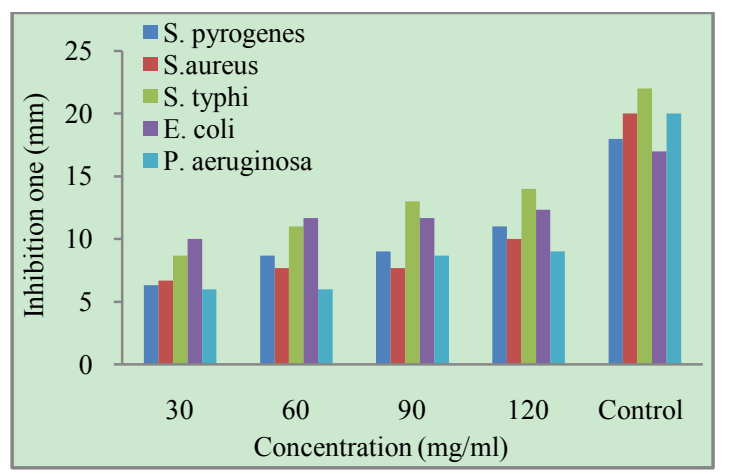

Figure 3. Diameter size of inhibition zone on the growth of different bacterial species due to application of different concentration of methanol extract of C. procera bark

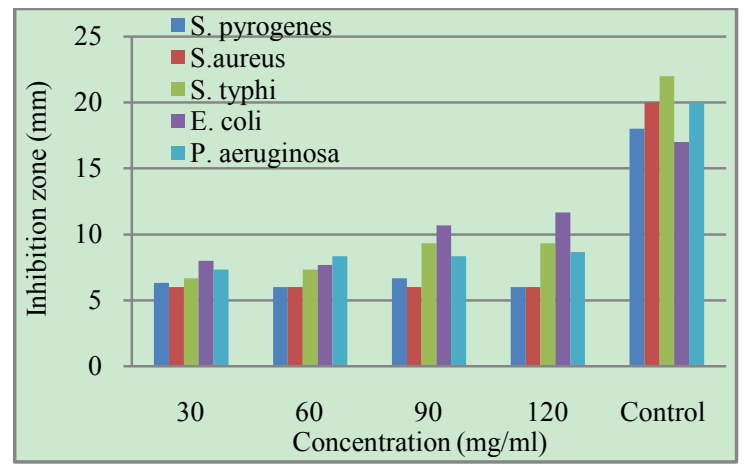

Figure 4. Diameter of inhibition zone on the growth of different bacterial species due to application of different concentration of methanol extract of C. procera fruit

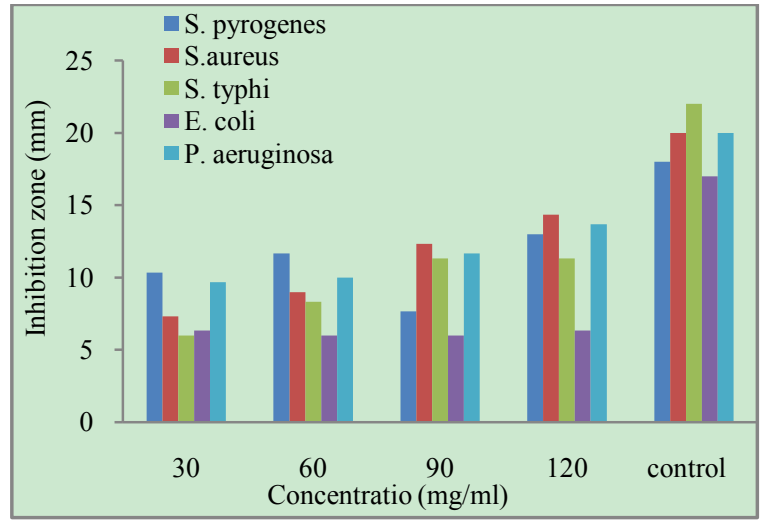

Figure 5. Diameter of inhibition zone on the growth of different bacterial species due to application of different concentration of ethanol extract of $C$. procera bark

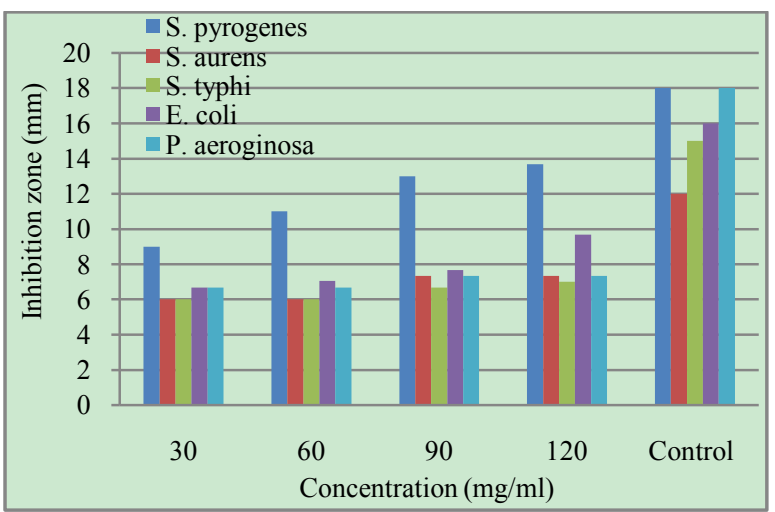

Note; Diameter of zone of inhibition is $6 \mathrm{~mm}$ and greater than $6 \mathrm{~mm}$ implies activity

Figure 6. Diameter of inhibition zone on the growth of different bacterial species due to application of different concentration of ethanol extract of $C$. procera fruit

\section{REFERENCES}

[1] Abubakar, S. (2006). Phytochemical Screening and Antibacterial Studies on Bauhinia refescens. A dissertation submitted to Postgraduate School of Usmanu Danfodiyo University, Sokoto

[2] Aderotimi, B. and Samuel, A. (2006). Phytochemical screening and antimicrobial assessment of Abutilon mavritianum, Bacopa monnifera and Datura stramonium. Biokemistri 18(1);39-44

[3] Agharkar, S. P. (1991). Medicinal plant of Bombay presidency. Scientific publication, India Pp 48-49

[4] Aliero, A.A., B.L. Aliero, and U. Buhari (2008). Preliminary Phytochemical and Antibacterial screening of Scadoxus maltiflorus, International Journal of Pure and Applied Sciences. 2(4); 13- 17

[5] Ashwari, K. (2009). Productivity of Calotropis procera and its use in renewable Energy, Science Blogging. http://www.scientificblogging.com/humboldt fellow and sc ience/productivity_calotropis_procera_and_its_use_renewab le_energy. retrieved on 5/01/2010 
[6] Bala, S.A. (2006). Common Ethnomedicinal plants of the semi arid regions of West Africa their description and phytochemicals, Triumph Publishing Company Limited Kano, Nigeria. Pp 193-196

[7] Cowan, M.M. (1999). Plants products as antimicrobial agents. Clin. Microbial Rev 12: 564-582

[8] Cheesbrough, M. (2001). District Laboratory Practice in Tropical Countries, part I Cambridge University Press. London Pp 157-206

[9] Elmarie, V.W. and Jonah, C.P. (2001). Purification and identification of active antibacterial component in Carpobrotus edulis L. Journal of Ethnopharmacol. 76: 87-91

[10] Fawole, M.O. (2001). Laboratory Manual of Microbiology, Spectrum Book Limited, Ibadan Pp 11- 14

[11] Gupta, M., Malumder, U.K., Kumar, S.T., Periyasamy, G. and Kumar, S.R (2004). Antioxidant and Hepatoprotective effecfs of Bauhinia racemosa against paracetamol and carbon tetrachloride induced liver damage in Rat. Pharmacol Toxicol Methods. 3: 12-20

[12] Hassan, S. W., Umar, R. A., Ebbo,A. A., and Matazu, I.K. (2005). Phytochemical, antibacterial and toxicity studies of Parkinsonia aculeate L. (Fabaceae), Nigerian Journal of Biochemistry and Molecular Biology. 20(2): 89-97

[13] Himalaya, (2002). Herbal monograph, Himalaya herbal healthcare. www.himalayahealthcare/researchpaper/index.hlm

[14] Kuta, F.A. (2008). Antifungal effects of C. procera stem back on Epidermophyton flocosum and Trichophyton gypseum. African Journal of Biotechnology. 7(13): 2116-2118

[15] Lewis, W.H. and Elvin Lewis, M.P. (1995) Medicinal plants as source of new therapeutics. Botanical Gard 82: 16-24

[16] Mohammad, S. and Dabai, Y.U. (2008). Antibacterial activity of some Nigerian plants, Science World Journal. 3(2): 43-44
[17] Ojo, O.O., Tella, I.O. and Ademola Aremu O.O. (2005). Effects of Azadiractha indica, Tamarindus indica and Eucalyptus camaldulensis on paracetamol induced lipid peroxidation in Rats, Journal of sustainable Development Agricultural Environment. 1:755-760

[18] Onomire, O. and Olorinfemi, P.O. (1998). Antibacterial screening and pharmacological evaluation of Dichrostachys cinerea nut, West Africa Journal of Biological Sciences. 7: 9-99

[19] Oudhia, P. (2001). Calotopis; useful weed. Society for panthenium management. Geeta Nagar, India

[20] Singh, U., A. M. Wadhwami, and B.M. John (1996). Dictionary of Economic plant of India, Indian Council of Agricultural Research, New Delhi, Pp 38-39

[21] Usman, H., Haruna, A.K., Akpulu, I.N., Ilyas, M., Ahmad, A.A., Musa, M.Y. (2005). Phytochemical and antibacterial screening of the leaf extracts of Celtis integrifolia (Lam). Journal of Tropical Biosciences. 5(2): 72-75

[22] Vohra, R. (2004). Calotropis the medicinal weed. Online medicinal book store, India

[23] Warrier, P.K., V. P.K. Nambiar, and C. Mankutty (1994). Indian medicinal plants, orient lonman; Chennai, India. Pp 341-345

[24] World Health Organization (WHO), (2003). The promotion and Development of traditional Medicine, Technical Report Series, 622

[25] World Health Organization (WHO), (2005). National policy on Traditional Medicine and Regulation of Herbal medicines, Report of global survey, Geneva

[26] Yesmin, M.N., Uddin, N.S., Sanzida, M., and Muhammad A. A. (2008). Antioxidant and Antibacterial Activities of Calotropis procera. American-Eurasian Journal of Agric and Environmental Science. 4 (5): 550-553 